\title{
Pollinating insects of cherimoya (Annona cherimola Miller) in La Molina, Lima, Peru
}

\author{
Insectos polinizadores del chirimoyo (Annona cherimola Miller) en La Molina, Lima-Perú
}

\author{
Morales, B. $\left({ }^{1}\right)^{*}$; Bautista, J.( $\left.{ }^{2}\right)$; Vergara, C. $\left({ }^{3}\right)$ \\ *Corresponding author: 20140959@lamolina.edu.pe \\ https://orcid.org/0000-0002-8879-3118
}

\begin{abstract}
This survey aimed to determine the pollinating insects of the flowers of the cherimoya crop (Annona cherimola Mill.) located at the Program of Research and Social Projection in Fruit Trees (PIPS-FRUTALES) at the Universidad Nacional Agraria La Molina. Fifteen trees were selected randomly, and evaluations were performed from 31 October to 15 November 2018. Three replicates were performed, each replicate was formed by a set of five trees and were evaluated in three different weeks. Each tree was evaluated in four quadrants, according to the location of the flowers (external or internal) and the floral phases of the crop (female or male). The collection of the insects from the cherimoya flowers was performed using an aspirator, then the insect morphotypes were determined and classified according to order, family, genus and/or species through the use of taxonomic dichotomous keys and the support of specialists. The collected insects belonged to the orders Coleoptera, Hymenoptera, and Hemiptera, with Coleoptera having the highest diversity (17 morphospecies) and quantity (242 specimens). The genus Europs (Monotomidae) proved to be the most abundant group of Coleoptera during the assessment period, followed by morphospecies of the families Nitidulidae, Anthicidae, Staphylinidae, Scarabaeidae, Anobiidae, and Buprestidae. The pollinating insects present in the cherimoya crop were satisfactorily classified into genera and species.
\end{abstract}

Keywords: Annona cherimola, Europs sp., floral phase, Monotomidae, pollinator

\section{Resumen}

El objetivo de esta investigación fue determinar la presencia de insectos polinizadores de las flores del cultivo de chirimoyo (Annona cherimola Mill.), ubicado en el Programa de Investigación y Proyección Social en Frutales (PIPSFRUTALES) de la Universidad Nacional Agraria La Molina. Se seleccionaron 15 árboles al azar y las evaluaciones se realizaron desde el 31 de octubre hasta el 15 de noviembre del 2018. Se realizaron tres repeticiones, cada repetición fue formada por un conjunto de cinco árboles y fueron evaluadas en tres semanas diferentes. Cada árbol fue evaluado en cuatro cuadrantes según la ubicación de las flores (externa o interna) y las fases florales del cultivo (hembra y macho). Se realizó la colecta de los insectos en las flores del chirimoyo empleando un aspirador, luego se determinaron los morfotipos de insectos y fueron clasificados de acuerdo al orden, familia, género y/o especie mediante el uso de llaves dicotómicas taxonómicas y el apoyo de especialistas. Los insectos colectados pertenecieron a las ordenes Coleoptera, Hymenoptera y Hemiptera, siendo el primero el predominante en diversidad (17 morfoespecies) y cantidad (242 individuos). El género Europs (Monotomidae) con una sola morfoespecie, resultó ser el grupo más constante y abundante de Coleoptera durante el período de evaluación, seguidos de morfoespecies de las familias Nitidulidae, Anthicidae, Staphylinidae, Scarabaeidae, Anobiidae y Buprestidae. Los insectos polinizadores presentes en el cultivo del chirimoyo fueron clasificados satisfactoriamente en géneros y especies.

Palabras claves: Annona cherimola, Europs sp., fase floral, Monotomidae, polinizador

\section{Introduction}

The cherimoya (Annona cherimola Miller) is native to subtropical areas of the Ecuadorian and Peruvian Andes (González, 2013). It belongs to the genus Annona, which comprises approximately 120 species, and is of great commercial importance (García et al., 2009). There is also growing interest in the commercialization of cherimoya, due to its pleasant flavor and aroma, and good acceptance in the market as an exotic fruit (González, 2013).

\footnotetext{
${ }^{1}$ Universidad Nacional Agraria La Molina. Student of the Faculty of Agronomy. Lima, Perú.

${ }^{2}$ Universidad Nacional Agraria La Molina. Agronomist Engineer. Lima, Perú.

${ }^{3}$ Universidad Nacional Agraria La Molina. Faculty of Agronomy. Department of Entomology, Lima, Perú.
} 
The expansion of the cultivation of cherimoya outside of the area of its native range has been limited by its floral behavior, called dicogamia protoginea (Guirado et al., 2001). This behavior consists of the early maturation of pistils wherein they are only receptive before the stamens of the same flower releases pollen (Franciosi, 1992). This characteristic of cherimoya flowers makes crosspollination necessary through the participation of natural pollinators (Ortiz-Sánchez \& Cabello-García, 1991).

The flowers of the cherimoya tree go through a cycle of floral opening that takes place in three consecutive phases, called the pre-female, female, and male phases (Guirado et al., 2001). In the pre-female phase, the flower is receptive, but it is not possible for it to be pollinated due to the reduced opening of the petals (Farré et al, 1999). Generally, beetles are introduced to the flowers in the female phase and remain inactive at the base of the petals or by walking on the stamens and stigmas. In the male phase, the beetles are dragged out of the flower due to falling petals and thus disperse to new flowers in the female state, covered with viable pollen for 24 hours (González et al., 2007).

In Annonaceae, natural pollination generally occurs by the action of insects, which are determined by the floral characteristics of the crop. The flowers of the cherimoya have a small floral chamber, which is why they are pollinated by small beetles belonging to the families Nitidulidae, Curculionidae, and Chrysomelidae (Gottsberger, 1999). The beetles are enticed to enter the flowers by the characteristic aroma of fermented fruit that the flowers release through osmophores located on the internal base of the petals (González et al., 2007). In addition, the fleshy petals serve as a food source for the insects (Meyer, 2003).

In Italy, studies on natural pollination in cherimoya have identified Orius laevigatus Fieber (HemipteraAnthocoridae) as the most important pollinator of Annona spp. (Caleca et al., 2002). In Florida, beetles of the family Nitidulidae are indicated as the main pollinators of fruit species of the genus Annona spp. (George et al., 1989). Recently, in the Caribbean Islands, the species Europs fervidus Blatchley was noted as the main pollinating agent of the atemoya fruit tree (Annona x atemoya) (Jenkins et al., 2015).

In Peru, no research has been reported yet focused on studying the pollinating insects of this crop. Therefore, it is necessary to determine these insects to establish an alternative, efficient system of pollination using insect species in the production area of this crop.

Taking this into account, the objective of this investigation was to determine the presence of insects associated with the pollination of cherimoya at La Molina, Peru. This information will allow future research to be carried out to determine the efficiency of these pollinating insects and to achieve better results in the production of this crop.

\section{Materials and Methods}

This research was carried out in the cherimoya plantation located in the fields at the Universidad Nacional Agraria La Molina (UNALM), La Molina district, Lima region, Peru, geographically located at latitude $12^{\circ} 4$ '58.51 "S, longitude $76^{\circ} 56^{\prime} 51.93$ "W, and $236 \mathrm{~m}$ above sea level. The field evaluations were carried out in seven-day intervals, beginning on October 31, 2018, and ending on November 15,2018 .

Fifteen trees were randomly selected and grouped in blocks, with five trees in each block. This was done to evaluate one block per week, that is, the evaluations were done on different trees weekly. Two hemispheres were evaluated in each tree: north and south. Each of these was divided into two strata (lower and upper half) and in each stratum four flowers were selected at random, of which two flowers were selected from the outside of the crown and two flowers from the inside of the crown.

\section{Field work}

The assessments were conducted during the period of greatest flower presence on the trees. Two floral stages of the crop were evaluated (female and male phases) and each evaluation was conducted over two continuous days.

Determination of the duration of the opening cycle of the flowers

Five trees were selected at random. In each tree four oneyear-old wooden branches and two flowers per branch were selected. These flowers were monitored from the prefemale phase to the fall of the petals (male phase). This was done to determine the duration and timing of each flower phase.

This assessment showed that the period of flower opening was approximately two days. Guirado et al. (2001) also pointed out that once the flower bud reaches its final size, the opening cycle takes place in two days. Based on the data obtained, the times of collection of the insects were determined.

\section{Collecting the insects}

The collections were made using an oral aspirator that included a collection bottle $(30 \mathrm{ml})$ that was introduced directly into the flower. On the first day, evaluations were made on flowers that were in the female phase, from 11:00 a.m. to 2:30 p.m. On the second day, on flowers in the male phase, from 3:00 to 6:30 p.m. The meteorological data of temperature $\left({ }^{\circ} \mathrm{C}\right)$ and relative humidity $(\%)$ were obtained from the "Von Humboldt" meteorological station located at the Universidad Nacional Agraria La Molina.

\section{Laboratory procedure}

Processing and checking the samples of the collecting vials

The insects collected in the field were taken to the insect preparation room of the Klaus Raven Büller Entomological 
Museum at the Universidad Nacional Agraria La Molina. In the room they were subjected to freezing for five hours to ensure death and to avoid deterioration of the insects, such as breaking legs and antennae.

\section{Classification}

Each sample was placed in a $6 \mathrm{~mm}$ diameter Petri dish and examined through a Motic SMZ -168 stereoscope, where the insects were separated into morphotypes. For this purpose, the following were considered: body coloration, elytra, pronotum, type of antenna, and shape and structure of the body.

\section{Coding}

The vials were labeled with the morphotype data and according to the taxonomic category in which they were provisionally classified. Each morphotype was coded using the first three letters of the taxon to which it belonged, at the order or family level, followed by a number (e.g. ColMorfo-1).

\section{Counting and recording}

Specimens classified in morphotypes and coded were counted by week and sector evaluated. The data obtained were recorded in a digital spreadsheet in Microsoft Excel.

\section{Assembly and preservation}

Three copies of each morphotype were assembled. Insects smaller than $15 \mathrm{~mm}$ were mounted on Canson cardboard points using gum arabic. Those with a length greater than $15 \mathrm{~mm}$ were mounted directly with an entomological pin. In this case, the pin went through the upper internal margin of the right elitre of the insect. Subsequently, the insects were labeled with the collection data. The insects of each morphotype that were not mounted were placed in $15 \mathrm{~mL}$ glass vials with $75 \%$ alcohol.

\section{Taxonomy determination}

In the taxonomic determination of the specimens, dichotomous keys of bibliographic sources were used, and specialists were consulted. Morphotypes were determined at the family level, some at the genus level, and others at the species level. Subsequently, the specimens were coded according to the standards followed in the insect collection of the Museo Entomológico Klaus Raven Büller of the Universidad Nacional Agraria La Molina, and were deposited in that collection. Photographs of each morphotype were also recorded using a Leica S8 APO Stereomicroscope connected to a Canon EOS 5D Mark III camera.

\section{Results}

A total of 373 specimens were recorded on cherimoya flowers corresponding to 17 morphotypes. The collected insects were distributed in three orders: Coleoptera, Hymenoptera, and Hemiptera, with order Coleoptera having the highest number of specimens (Table 1). The most abundant insect families were Monotomidae and Nitidulidae, order Coleoptera; and Formicidae, order Hymenoptera.

\section{Insects collected on cherimoya flowers}

There were 177 specimens in the female phase of the flowers and 196 in the male phase (Table 1), with no significant difference between the two phases, according to Tukey's mean comparison test $(\alpha=0.05)$. The lowest number of specimens was recorded in the first two weeks of collections with a total of 106 and 119 specimens respectively, with the female phase showing the highest number, while in the third week 148 specimens were recorded, with the male phase showing the highest number.

\section{Order Coleoptera}

In the order Coleoptera, the presence of a species to be determined from the genus Europs (Fig. 1), belonging to the family Monotomidae, was repeatedly recorded. This species was dominant in all evaluations but was present to a greater extent in the male phase of the flowers.

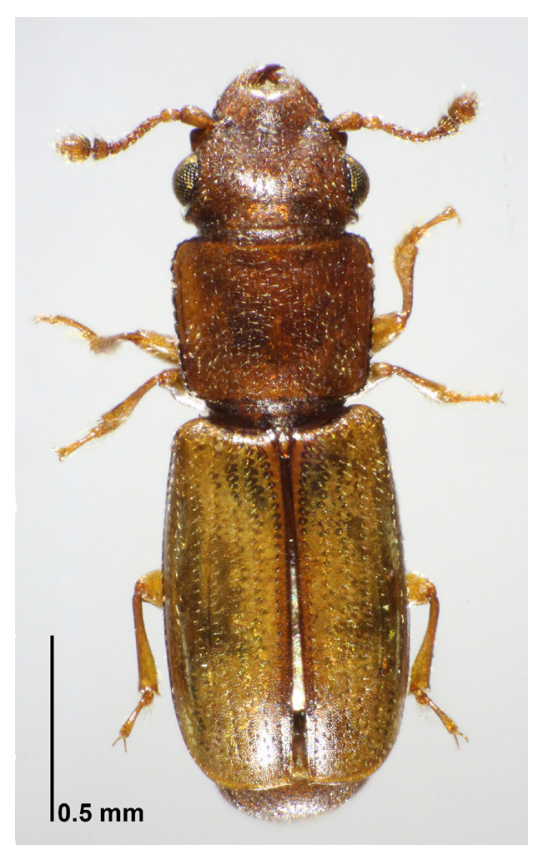

Figure 1. Adult Europs sp. (Order Coleoptera, Family Monotomidae).

The family Nitidulidae presented the highest diversity of specimens, with species from the genera Colopterus, Urophorus, and Carpophilus. The genus Colopterus turned out to be the most diverse group with four species, while the genera Urophorus (Fig. 2) and Carpophilus presented one species each, with the species Carpophilus hemipterus (Linnaeus, 1758) being determined for Carpophilus (Fig. 3). 
Table 1. Order, family, genus, species, and number of specimens collected in the female and male phase of cherimoya flowers from October 31 to November 15, 2018, La Molina, Lima, Peru

\begin{tabular}{|c|c|c|c|c|c|}
\hline \multirow{2}{*}{ Order } & \multirow{2}{*}{ Family } & \multirow{2}{*}{ Genus/species } & \multicolumn{2}{|c|}{ Number of specimens by phase } & \multirow{2}{*}{ Total } \\
\hline & & & Female & Male & \\
\hline \multirow{3}{*}{ Hemiptera } & \multirow{2}{*}{ Aphididae } & Aphis spiraecola & 9 & 10 & 19 \\
\hline & & Greenidia ficicola & 3 & 0 & 3 \\
\hline & Pseudococcidae & Planococcus citri & 8 & 3 & 11 \\
\hline \multirow{12}{*}{ Coleoptera } & Anobiidae & Unidentified & 0 & 2 & 2 \\
\hline & Anthicidae & Anthicus sp. & 5 & 3 & 8 \\
\hline & Buprestidae & Chrysobothris sp. & 1 & 0 & 1 \\
\hline & Monotomidae & Europs sp. & 78 & 128 & 206 \\
\hline & \multirow{6}{*}{ Nitidulidae } & Urophorus sp. & 3 & 1 & 4 \\
\hline & & Colopterus sp.1 & 0 & 1 & 1 \\
\hline & & Colopterus sp.2 & 2 & 8 & 10 \\
\hline & & Colopterus sp. 3 & 1 & 0 & 1 \\
\hline & & Colopterus sp.4 & 2 & 1 & 3 \\
\hline & & Carpophilus hemipterus & 3 & 0 & 3 \\
\hline & Scarabaeidae & Paranomala undulata peruviana & 2 & 0 & 2 \\
\hline & Staphylinidae & Unidentified & 0 & 1 & 1 \\
\hline \multirow{2}{*}{ Hymenoptera } & \multirow{2}{*}{ Formicidae } & Linepithema humile & 59 & 38 & 97 \\
\hline & & Tapinoma melanocephalum & 1 & 0 & 1 \\
\hline Total & & & 177 & 196 & \\
\hline
\end{tabular}

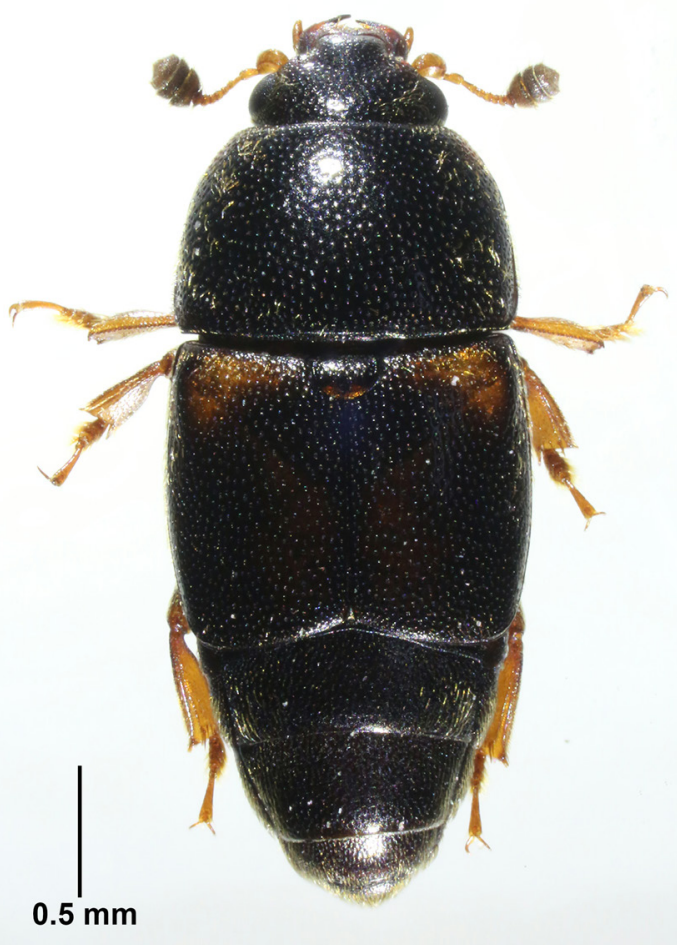

Figure 2. Adult Urophorus sp. (Order Coleoptera, Family Nitidulidae).

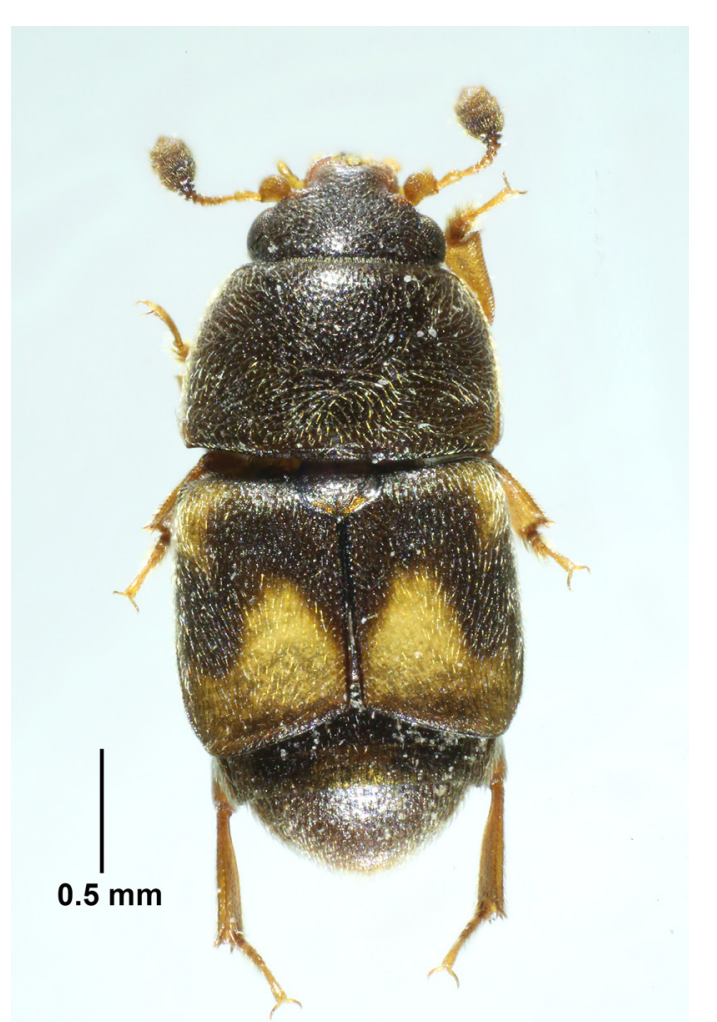

Figure 3. Adult Carpophilus hemipterus. (Order Coleoptera, Family Nitidulidae). 
In the collection, the species Paranomala undulata peruviana (Guérin-Méneville, 1831) (Family Scarabaeidae), species from the genera Anthicus (Anthicidae) and Chrysobothris (Buprestidae), and the families Staphylinidae and Anobiidae were also recorded. All of these were collected from the flowers in a smaller proportion than the other families.

\section{Order Hymenoptera}

The Order Hymenoptera was the group with the second highest number of specimens, with the presence of species Linepithema humile (Mayr, 1868) and Tapinoma melanocephalum (Fabricius, 1793) from the family Formicidae. Both species occurred in greater numbers in the female phase.

\section{Order Hemiptera}

The Aphididae family was recorded, represented by the species Aphis spiraecola (Patch, 1914) and Greenidia ficicola (Takahashi, 1921). The Pseudococcidae family was recorded, represented by the species Planococcus citri (Risso, 1813).

\section{Discussion}

\section{Number of insects collected according to the flower phase of the crop}

During the investigation, a greater number of insects were obtained in the male phase of the flowers compared to the female phase, showing a significant difference in the number of specimens captured in both phases. This is contrary to the findings of Tsukada et al. (2005), who studied cherimoya flower visitors in Italy and found no significant difference in the composition of flower visitors between the male and female phases.

The greater number of insects collected during the male phase could be related to the arrangement of the flower, since according to González et al. (2007) during this phase there is an opening at the base of the petals which allows insects to enter in search of food or shelter.

\section{Order Coleoptera}

Among the groups of insects found, the order Coleoptera was predominant, similar to results by Tsukada et al. (2005) who found 20 species from that order on cherimoya flowers in Japan, and Caleca et al. (2002), who obtained 24 species of Coleoptera out of the 49 species collected on flowers of Annona sp. and certain hybrids in experimental orchards in Sicily.

According to Stefanescu et al. (2018), the biology of the larval stages of Coleoptera is usually different from the adult stage, with adults visiting flowers for reasons related to obtaining food (from pollen, nectar, and/or floral tissues), mating, and/or protection from predators. Therefore, the higher incidence of insects of the order Coleoptera in flowers may be related to the type of diet they require (in this case pollen), and to fulfill their life cycle satisfactorily. In addition, they possess morphological adaptations, both oral system and of the integument with its hairy covering, in which pollen grains may adhere and then pass to other flowers (Krenn et al., 2005).

Within this order, the presence of a species (still to be determined) from the genus Europs (Family Monotomidae) was consistently recorded. This species turned out to be the predominant species, which coincides with other research on Annonaceae flowers, where it is cited as the most common visitor, followed by Loberus testaceus Reitter (Erotylidae) (Jenkins et al., 2013). Among families collected in this investigation, the family Nitidulidae was the most diverse, with six species within the genera Colopterus, Urophorus, and Carpophilus. This family was also cited among the flower visitors in Japan by Tsukada et al. (2005).

\section{Order Hymenoptera}

The incidence of Linepithema humile and Tapinoma melanocephalum in flowers may be related to the presence of insects of the Order Hemiptera. According to Vergara et al. (2007), a trophobiotic relationship between Formicidae and Hemiptera exists in which the ants feed on the honeydew excreted by the members of the Coccoidea superfamily. This coincides with what was found in the evaluated flowers, since in addition to ants, Aphis spiraecola and Planococcus citri (Hemiptera) were found.

\section{Order Hemiptera}

The presence of Aphis spiraecola and Greenidia ficicola in cherimoya flowers may be related to their feeding habit, according to Rosales-López et al. (2013), who pointed out that aphids are polyphagous insects that inhabit different plant organs and therefore can be found in flowers. On the other hand, the presence of Planococcus citri in flowers is related to their feeding habits. According to Rao et al. (2006), this species is polyphagous and cosmopolitan, and may be found in shoots, fruits, and flowers.

\section{Conclusions}

In the flowers of the cherimoya crop in the agricultural field of La Molina, 17 morphotypes of insects belonging to the orders Coleoptera, Hymenoptera, and Hemiptera were found.

The order Coleoptera was the most abundant, with the family Monotomidae best represented in abundance throughout the collection period, as well as one species in the genus Europs.

The order Hymenoptera was the second most abundant group, represented only by the family Formicidae, 
with the species Linepithema humile and Tapinoma melanocephalum.

To a lesser extent, the order Hemiptera, with the family Aphididae represented by the species Aphis spiraecola and Greenidia ficicola, and the family Pseudococcidae represented by the species Planococcus citri were present. These species are not considered pollinating insects; however, they are of agricultural importance since they are considered pests.

\section{Acknowledgements}

We thank the Ministerio de Educación del Perú for funding this research. We are grateful to the researchers Alfredo Giraldo, Walter Díaz, Nidia Elguera, Laura Cruz, and Carmen Livia for their support in managing and determining the specimens collected, and for guidance in processing the data. We would like to thank the Program of Research and Social Projection in Fruit Trees (PIPSFRUTALES) at the Universidad Nacional Agraria La Molina for granting permission to carry out the collections in the cherimoya fields.

\section{References}

Caleca, V., Lo Verde, G., Salvatore, R., \& Haralabos, T. (2002). Insect and hand pollination of Annona spp. in Sicily. Phytophaga, 12(1), 117-127.

Farré, J., Hermoso, J., Guirado, E., \& García-Tapia, J. (1999). Techniques of cherimoya cultivation in Spain. Acta Horticulturae, 497(5), 91-118. https:// doi.org/10.17660/ActaHortic.1999.497.5

Franciosi, R. (1992). El cultivo de chirimoyo en el Perú. Lima, Perú: Fundeagro.

García, W., Guzmán, B., Lino, W., Rojas, J., Hermoso, J., Girado, E., González, J., Scheldeman, X., \& Hormaza, I. (2009). Manual de Manejo Integrado del Cultivo de Chirimoyo. Cochabamba, Bolivia: Alemán \& Cabrera.

George, A., Nissen, R., Ironside, D., \& Anderson, P. (1989). Effects of nitidulid beetles on pollination and fruit set of Annona spp. hybrids. Scientia Horticulturae, 39(1), 289-299. https://doi.org/10.1016/03044238(89)90122-2

González, M. (2013). Chirimoya (Annona cherimola Miller), frutal tropical y sub-tropical de valores promisorios. Revista Cultivos Tropicales, 34(3), $52-63$.

González, M., Hueso, J., Alonso, F., \& Cuevas, J. (2007). Mejora de la productividad y calidad del fruto mediante el control de la polinización en Chirimoyo.
España: Fundación Cajamar..

Gottsberger, G. (1999). Pollination and evolution in Neotropical Annonaceae. Plant Species Biology, 14(2), 143-152. https://doi.org/10.1046/j.14421984.1999.00018.x

Guirado, E., Hermoso, J., Perez de Oteyza, A., García-tapia, J., \& Farré, J. (2001). Polinización del chirimoyo. Granada, España, Junta de Andalucía. Granada, España: Consejería de Agricultura y pesca .

Jenkins, D.A., Cline, A., Irish, B.M., \& Goenaga, R.J. (2013). Attraction of pollinators to atemoya (Magnoliales: Annonaceae) in Puerto Rico: A synergetic approach using multiple nitidulid lures. Journal of Economic Entomology, 106, 305-310. https://doi.org/10.1603/EC12316

Jenkins, D.A., Millan-Hernandez, C., Cline, A.R., McElrath, T.C., Irish, B., \& Goenaga, R. (2015). Attraction of pollinators to Atemoya (Annona squamosa $\mathrm{x}$ Annona cherimola) in Puerto Rico using commercial lures and food attractants. Journal of economic entomology, 108(4), 1923-1929. https:// doi.org/10.1093/jee/tov136

Krenn, H., Plant, J., \& Szucsich, N. (2005). Mouthparts of flower-visiting insects. Arthropod Structure \& Development, 34, 1-40. https://doi.org/10.1016/j. asd.2004.10.002

Meyer, W. (2003). Tropical fruit pests and pollinators: biology, economic importance, natural enemies, and control. Florida Entomological Society, $86(3), \quad 385 . \quad$ https://doi.org/10.1653/00154040(2003)086[0385:BR]2.0.CO;2

Ortiz-Sánchez, F.G., \& Cabello-García, T. (1991). Utilización de insectos en la polinización de los cultivos subtropicales. Revista Agrícola Vergel, 119, 692-694.

Rao, C., Shivankar, V., \& Shyam, S. (2006). Citrus mealy bug (Planococcus citri Risso) management - a review. Agricultural reviews, 27(2), 142-146.

Rosales-López, A., Flores-Dávila, M., Aguirre-Uribe, L., González, R., Villegas-Jiménez, N., \& Vega-Ortíz, H. (2013). Diversidad de áfidos (Hemiptera: Aphididae) en el sureste de Coahuila. Revista Mexicana de Ciencias Agrícolas, 4(7), 987-997.

Stefanescu, C., Aguado, L., Asís, J., Baños-Picón, L., Cerdá, X., García, M., Micó, E., Ricarte, A., Tormos, J. (2018). Diversidad de insectos polinizadores en la península ibérica. Ecosistemas, 27(2), 9-22. https:// doi.org/10.7818/ECOS.1391

Tsukada, M., Higuchi, H., Furukawa, T., \& Yoshida, A. (2005). Flower visitors to cherimoya, Annona 
cherimola (Magnoliales: Annonaceae) in Japan. Applied Entomology and Zoolog, 40(2), 317-324. https://doi.org/10.1303/aez.2005.317

Vergara, E.V., Echavarría, H., \& Serna, F.J. (2007). Hormigas (Hymenoptera: Formicidae) Asociadas al arboretum de la Universidad Nacional de Colombia, Sede Medellín. Sociedad Entomológica Aragonesa, 40, 497-505. 